\title{
Characteristics of natural rubber - carbonized pawpaw seed composites
}

\author{
Emmanuel OSABOHIEN*, Ufuoma SOYA and Nduka Obichukwu OJEIFO \\ Department of Chemistry, Delta State University, Abraka, Nigeria. \\ *Corresponding author; E-mail: osabohieneemma@yahoo.com; Tel. (+234) 8036761310
}

\begin{abstract}
The search for eco-friendly and less expensive fillers and additives has necessitated the use of renewable natural resources of plant origin in rubber compounding. This research work utilized carbonized pawpaw (Carica papaya) seeds as filler in natural rubber compounds in a bid to determining the reinforcing potentials. The carbonized pawpaw seeds (CPS) and dried raw pawpaw seeds (RPS) were separately pulverized, screened with a $75 \mu \mathrm{m}$ sized test sieve and incorporated into natural rubber, Standard Nigerian Rubber (SNR 10), loaded between $0-50$ parts per hundred (Phr) of the rubber. The cure characteristics, physicomechanical properties as well as the percentage swelling characteristics of vulcanizates were measured as a function of filler loading and compared with the values obtained using industrial grade carbon black (N330) as a standard reinforcing filler. Results showed that the CPS and RPS filled SNR 10 influenced the cure characteristics and physicomechanical properties of rubber vulcanizates. The scorch and cure times of the vulcanizates decreased as filler loading is increased while maximum torque increased with increase in filler loading. Tensile strength and modulus at $100 \%$ strain for all SNR 10 filled vulcanizates increased to optimum level at $40 \mathrm{phr}$ respectively, thereafter decreased, and elongation at break decreased as filler loading is increased. The hardness and abrasion resistance of the vulcanizates increased with increase in filler loading, while compression set and percentage swelling in both petroleum and aromatic solvents decreased as filler loading is increased. The vulcanizates tend to swell more in aromatic solvents than in petroleum solvents. Percentage swelling of the vulcanizates (N330 - SNR $10<$ CPS SNR $10<$ RPS - SNR 10) and in the order benzene > toluene > kerosene > diesel solvents. The research work showed that CPS and RPS fillers exhibited considerable reinforcing potentials but somewhat inferior to carbon black, N330.
\end{abstract}

(C) 2020 International Formulae Group. All rights reserved.

Keywords: Natural rubber, pawpaw seeds, fillers, vulcanizates and reinforcement.

\section{INTRODUCTION}

Natural rubber (NR) is a renewable naturally occurring polymer. Application of NR in many areas has been known for a long time. Over the years, the popularity and demands for natural rubber materials have experienced a steady growth, especially in recent times (Akinlabi et al., 2011). It is extracted in the form of latex by tapping from the bark of the Hevea tree. The latex is collected and processed through a series of steps involving; preservation, concentration, coagulation and drying (Blow and Hepburn, 1982). Modified natural rubbers are also available, with treatment usually performed at the latex stage (Osabohien, 2012; Chaiwat et al., 2013). Manufacturing rubber articles involves the use of additives which allow the rubber compounds to be satisfactorily processed and when vulcanised improve the application properties of the articles (Okoh et 
al., 2008; Osabohien, 2010; Chaiwat et al., 2013).

Particulate filler such as carbon black is commercially very important and has been widely used as reinforcing filler, but its high cost due to its production process derivable from petroleum has led to local sourcing of alternative fillers that will provide good reinforcing properties at reduced cost (Osabohien and Egboh, 2007b; Akinlabi et al., 2011). It has been reported that plant materials and natural fibre-reinforced biocomposites are light in weight, have good physicomechanical properties, renewable, easily recycled and exhibit high resistance to corrosion and weather changes, biodegradable, low cost, and environmentally friendly (Osabohien et al., 2015). In previous reports, plant materials that can serve as fillers include; jute, raffia, pineapple leaf fibre, coconut fibre, flax, wood, cocoa pod husk, plantain peels, groundnut shell, rubber seed shell, cherry seed shell, Velvet tamarind seed shell, Calamus deerratus fibre (Wang et al, 2003; Osabohien et al., 2006; Okoh et al., 2008; Osabohien and Egboh, 2008; Abu-Bakar et al., 2012; Chaiwat et al., 2013; Imoisili et al., 2013; Osabohien et al., 2015).

Papaya, also called pawpaw is a succulent fruit of a large plant (Carica papaya) of the family Caricaceae that is considered a tree, though its palm like trunk, up to $8 \mathrm{~m} \mathrm{(26}$ feet) tall, is not as woody as the designation generally implies. All parts of the plant contain latex in articulated laticifers grown in most parts of Nigeria (Morton and Miami, 1987; Heywood et al., 2007). Papaya is used in some toothpastes, shampoo, and facial creams. It has been used widely in folk medicine for many ailments (Der Marderosian and Beutler, 2010). This study investigates the potentials of pawpaw seeds (dried and carbonized) on the cure characteristics and the physicomechanical properties of natural rubber compounds as compared to standard N330 filler.

\section{MATERIALS AND METHODS Materials}

The materials used for this study include pawpaw seeds obtained from local fruit seller at Abraka, Delta State, Nigeria. Standard Nigerian Rubber (SNR 10) was obtained from Foot-wear Accessories, Manufacturing and Distribution (FAMAD), Benin City, Nigeria. Industrial grade carbon black, (N330) was obtained from Nigerian National Petroleum Corporation (NNPC), Warri, Delta State, Nigeria, Industrial grade rubber compounding additives and rubber testing equipment were obtained from the Department of Polymer Technology, Auchi Polytechnic, Auchi, Edo State, Nigeria and Rubber Research Institute of Nigeria (RRIN), Iyanomo, Benin City, Nigeria, respectively. The atomic absorption spectrophotometer (AAS), PyeUnicam SP 2900 model, used for the analysis of metallic contents was obtained from Petroleum Training Institute (PTI), Effurun, Delta State, Nigeria and Fourier Transform Infrared (FTIR) Spectrophotometer was obtained from Obafemi Awolowo University, IIe-Ife, Osun State, Nigeria.

\section{Methods \\ Preparation and characterization of sourced materials}

Raw pawpaw seeds (RPS) were obtained by grinding dried pawpaw seeds. While the carbonized pawpaw seed (CPS) was got by carbonizing ground pawpaw seeds in a furnace at $600{ }^{\circ} \mathrm{C}$ for an hour. The RPS and CPS were pulverized by means of Corona hand mill and sieved separately using standard test sieve of mesh size, $75 \mu \mathrm{m}$. The samples were characterized in terms of moisture content, loss on ignition, iodine adsorption number, density, metallic and non-metallic contents and $\mathrm{pH}$ of aqueous slurry in comparison with the N330 using standard test methods (Vogel, 1978; ASTM D1512-15, 2015).

\section{Compounding and curing}

The formulation recipe for the NR compounds is given in Table 1 using efficient vulcanization (EV) system. The compounds were mixed and masticated with the use of a laboratory two-roll mill of size $160 \times 320 \mathrm{~mm}$ maintained at $80{ }^{\circ} \mathrm{C}$, using a batch factor of 7 . Unvulcanized samples were die cut and tested for the cure characteristics using Monsanto 
rheometer MDR, 2000 model. Compression moulding in a steam heated and hydraulically operated daylight press with a pressure of 150 $\mathrm{kg} / \mathrm{cm}^{2}$ at a temperature of $180{ }^{\circ} \mathrm{C}$ was used to cure the compounded natural rubber, at the different cure times deduced from the Monsanto rheographs (Okoh et al., 2014; Osabohien and Ojeifo, 2017).

\section{Physicomechanical properties of vulcanizates}

Monsanto Instron Tensometer (model 4301) at a crosshead speed of $500 \mathrm{~mm} /$ minute at room temperature using the dumb-bell shaped test pieces, according to standard procedures was used to measure the tensile properties (tensile strength, modulus and elongation at break) of the vulcanizates (ASTM D412, 2010; Okoh et al., 2014; Osabohien and Ojeifo, 2017).

The abrasion resistance of the test sample was determined using the Wallace test equipment (serial no. C85015/1) in accordance with standard methods (BS, 1982). Where; $\mathrm{S}=$ volume loss per 1000 revolutions of abrasive wheel calculated from the mean of the four runs on standard sample. $\mathrm{T}=$ volume loss per 1000 revolutions of abrasive wheel from the mean of the four runs on the test sample.

Abrasion resistance index $=\mathrm{S} / \mathrm{T} \mathrm{x}$ 1000, as described by Sogbaike et al' 2005 .

Monsanto Duratron, 2001 was used to determine the hardness of the cured SNR 10 vulcanizate test pieces in accordance with the procedure described in BS 903 part A26, 1958.

Wallace compression set machine (serial no. C88053/1) was used to determine the compression set of the vulcanizates. Where, $t_{0}=$ the original specimen thickness and $t_{1}=$ the specimen thickness when compression set.

Compression set $\%=\left(\mathrm{t}_{0}-\mathrm{t}_{1}\right) / \mathrm{t}_{0} \times 100$

The $\%$ swelling of the vulcanizates in petroleum solvents (diesel and kerosene) and organic solvents (toluene and benzene) were determined by using the method described in (Osabohien and Ojeifo, 2017). Rectangular shaped test pieces were die cut from each of the $1 \mathrm{~mm}$ thick cured samples, weighed and introduced into each solvent in plastic containers, which were then tightly covered to exclude air and set aside for 48 hours at $25{ }^{\circ} \mathrm{C}$. Each of the samples was removed from the container, dried between filter papers and reweighed immediately. The change in weight of each sample was expressed as percentage swelling in the following equation as described by Sogbaike et al. (2005) and Osabohien and Ojeifo (2017).

$\%$ Swelling $=\left(\mathrm{W}_{2}-\mathrm{W}_{1}\right) / \mathrm{W}_{1} \times 100$

Where: $W_{1}$ and $W_{2}=$ initial weight of each test sample and final weight of swollen sample respectively.

\section{RESULTS}

The results of the forgoing reports are shown below; Table 1 presents the formulation recipe for the natural rubber, SNR 10 - filler composites, while Table 2 shows the physicochemical properties of the fillers, N330, CPS and RPS used. The moisture content at $110{ }^{\circ} \mathrm{C}$, loss on ignition at $1000{ }^{\circ} \mathrm{C}$, iodine adsorption number $(\mathrm{mg} / \mathrm{g}), \mathrm{pH}$ of aqueous slurries, $\mathrm{Mg}, \mathrm{Na}, \mathrm{K}$ and $\mathrm{Fe}$ contents (ppm) and the density of the fillers were presented.

Figures 1-3 are results of the cure characteristics of the SNR 10 - filler composites, i.e, the scorch times, cure times and maximum torques of the rubber - filler composites. Figures $4,5 \& 6$ reported the tensile properties of the rubber - filler vulcanizates i.e the tensile strength, modulus and elongation at break respectively. Figure 7 presented the hardness properties, Figure 8 showed the abrasion resistance index while Figure 9 depicted the compression set results of the rubber vulcanizates. Figures 10-13 showed the results of the percentage swelling properties of SNR 10 filled with N330, CPS and RPS in solvents, diesel, kerosene, benzene and toluene at $25{ }^{\circ} \mathrm{C}$ respectively. 
Table 1: Recipe for the NR compounds.

\begin{tabular}{lc}
\hline \multicolumn{1}{c}{ Ingredient } & phr \\
\hline SNR 10 & 100 \\
Zinc oxide & 4.0 \\
Stearic acid & 2.0 \\
** Filler & $0.0-50.0$ \\
Processing oil & 2.0 \\
*CBS & 2.0 \\
*TMQ & 1.5 \\
Sulphur & 1.5 \\
\hline *CBS = N-Cyclohexylbenzothiazyl sulphonamide, TMQ = 2, 2, 4-trimethyl-1, 2-dihydroquinoline. \\
** Filler loading, $0.0,10.0,20.0,30.0,40.0,50.0$ Phr of SNR 10.
\end{tabular}

Table 2: Physicochemical properties of N330, CPS and RPS.

\begin{tabular}{lccc}
\hline Parameters & N330 & CPS & RPS \\
\hline Moisture content at $110^{\circ} \mathrm{C}(\%)$ & 1.53 & 1.60 & 2.23 \\
Loss on ignition at $1000{ }^{\circ} \mathrm{C}(\%)$ & 92.0 & 85.00 & 78.00 \\
Iodine Adsorption number $(\mathrm{mg} / \mathrm{g})$ & 76.40 & 65.10 & 58.30 \\
$\mathrm{pH}$ of aqueous slurry & 6.48 & 6.10 & 5.73 \\
Magnesium $(\mathrm{ppm})$ & Trace & 5.10 & 4.69 \\
Sodium $(\mathrm{ppm})$ & Trace & 4.17 & 1.71 \\
Potassium $(\mathrm{ppm})$ & Trace & 4.50 & 5.50 \\
Iron $(\mathrm{ppm})$ & Trace & 3.50 & 2.12 \\
Density $\left(\mathrm{g} / \mathrm{cm}^{3}\right)$ & 1.70 & 1.50 & 1.80 \\
\hline
\end{tabular}

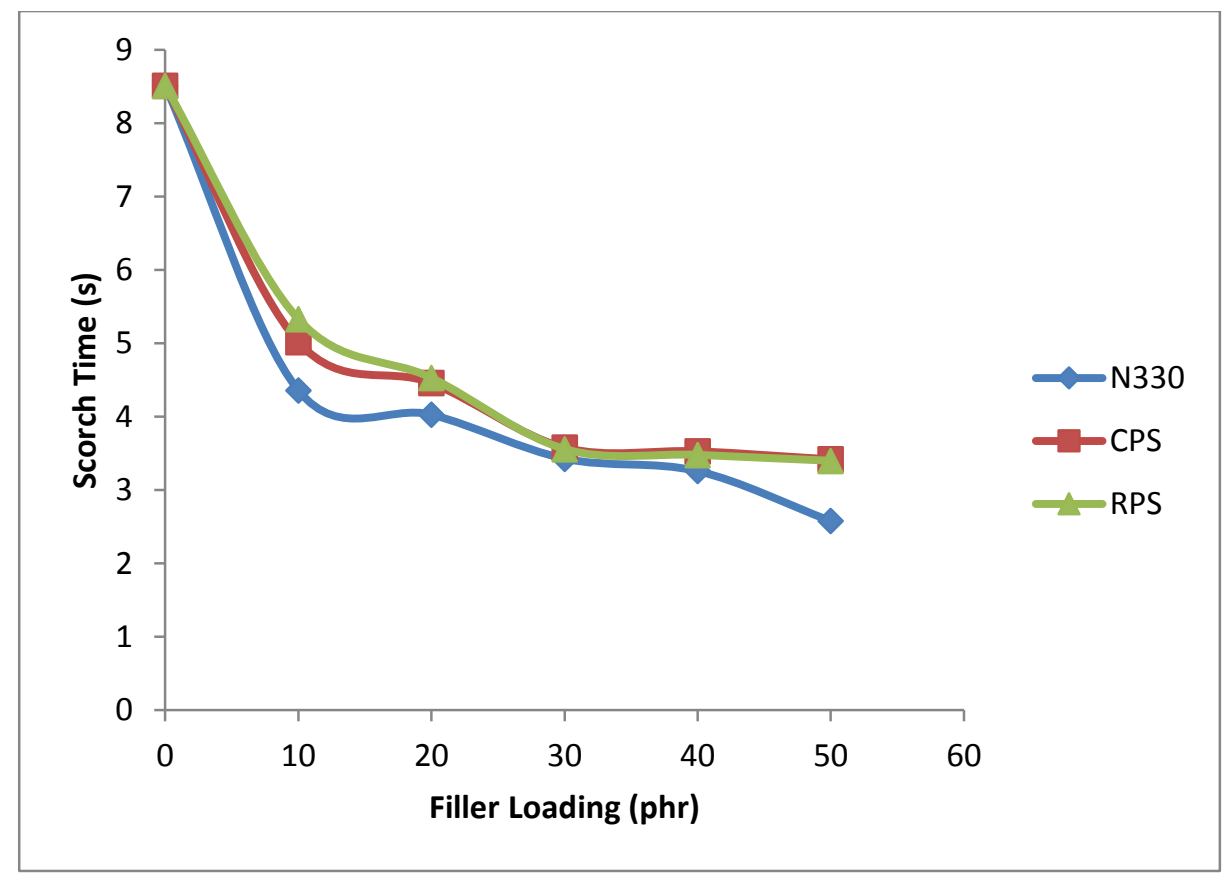

Figure 1: Effect of filler loading on scorch time of SNR 10 filled with N330, CPS and RPS. 


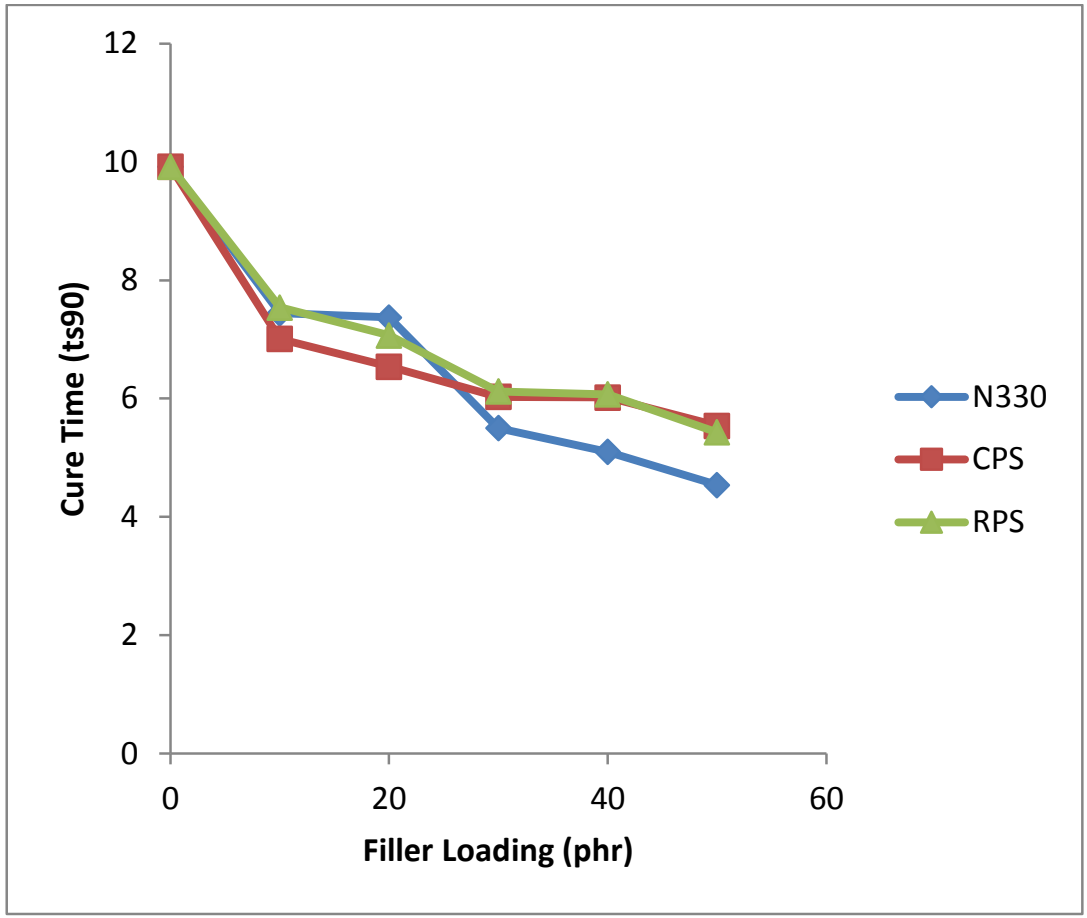

Figure 2: Effect of filler loading on cure time of SNR 10 filled with N330, CPS and RPS.

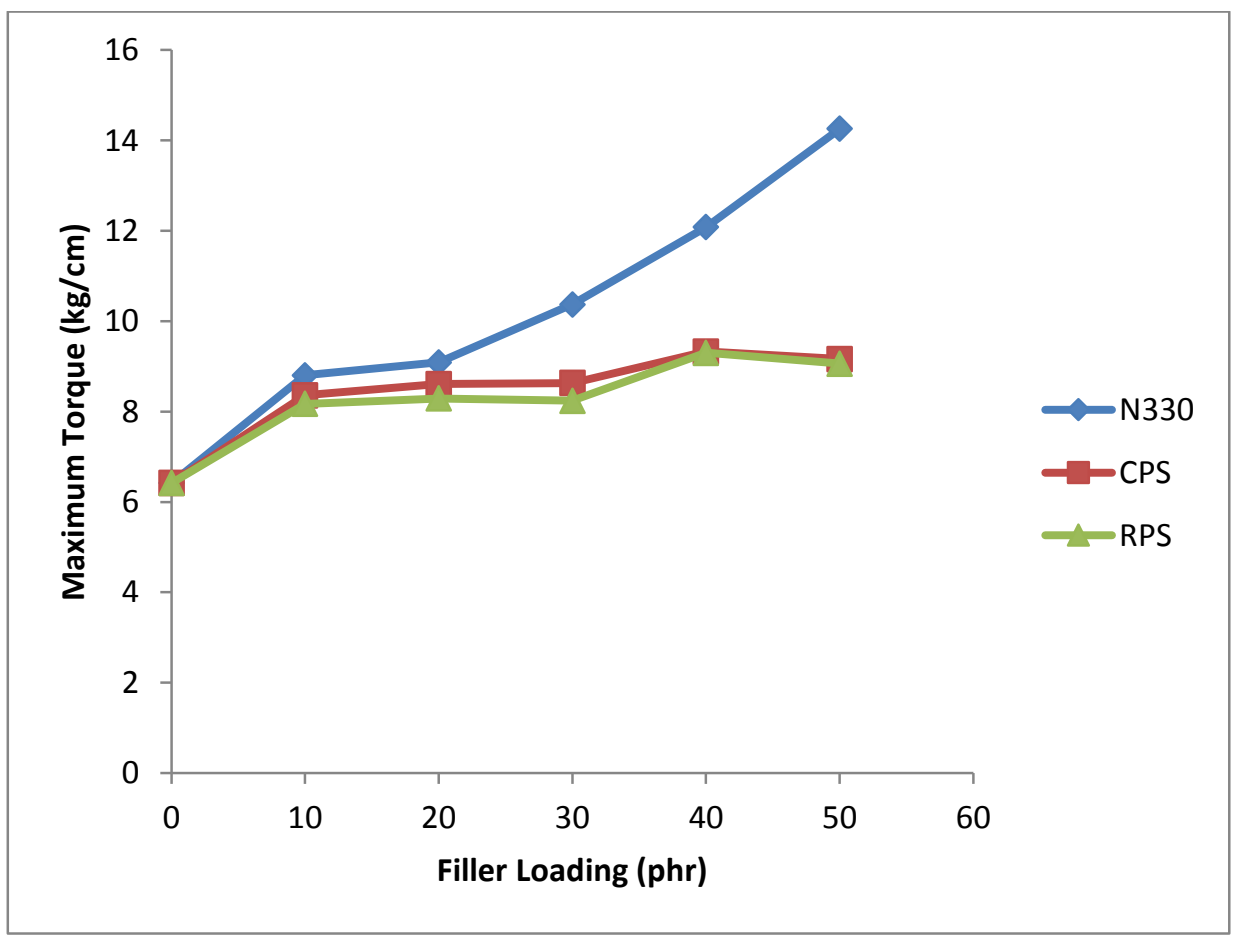

Figure 3: Effect of filler loading on Max. Torque (Tmax) of SNR 10 filled with N330, CPS and RPS. 


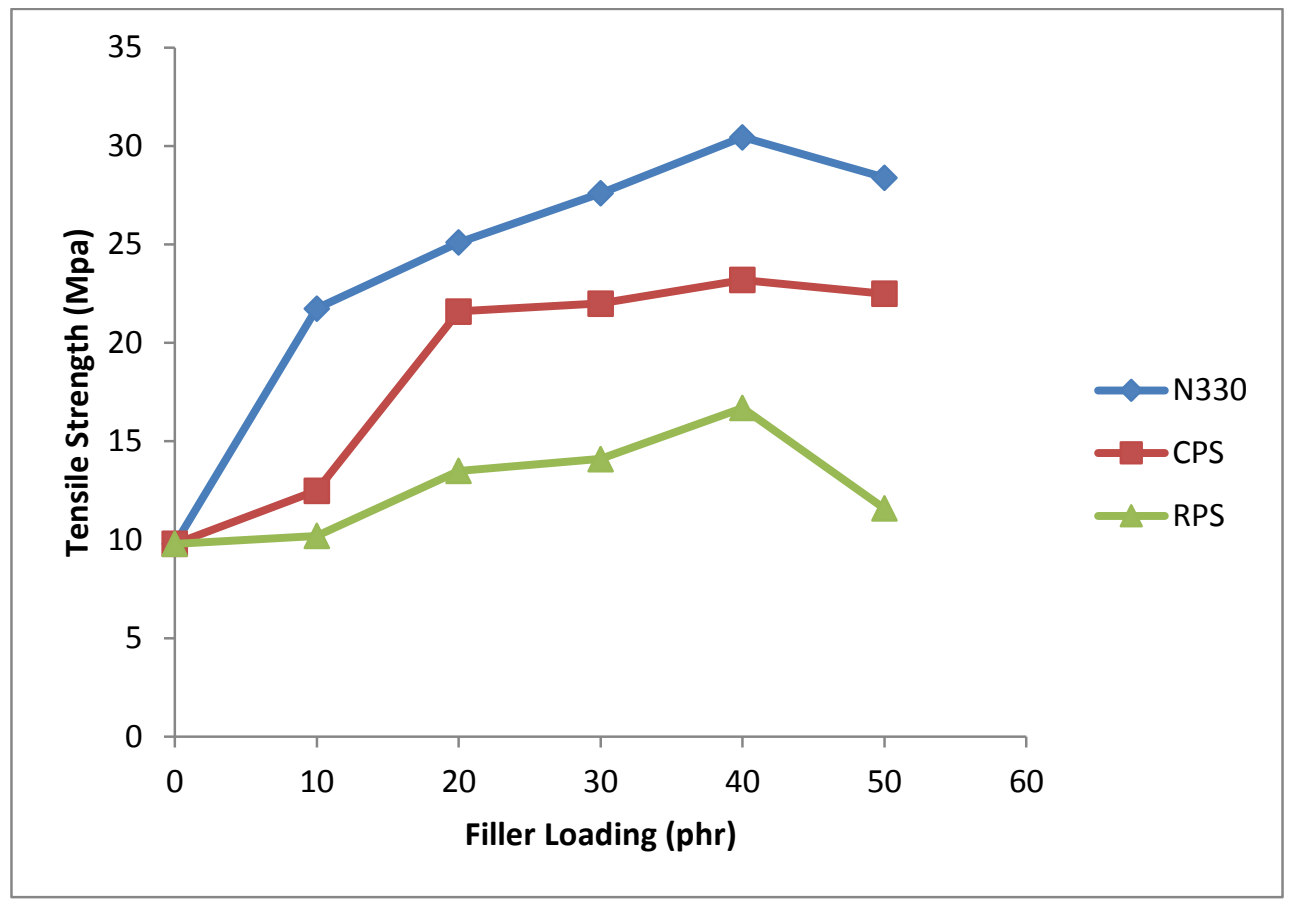

Figure 4: Effect of filler loading on tensile strength of SNR 10 filled with N330, CPS and RPS.

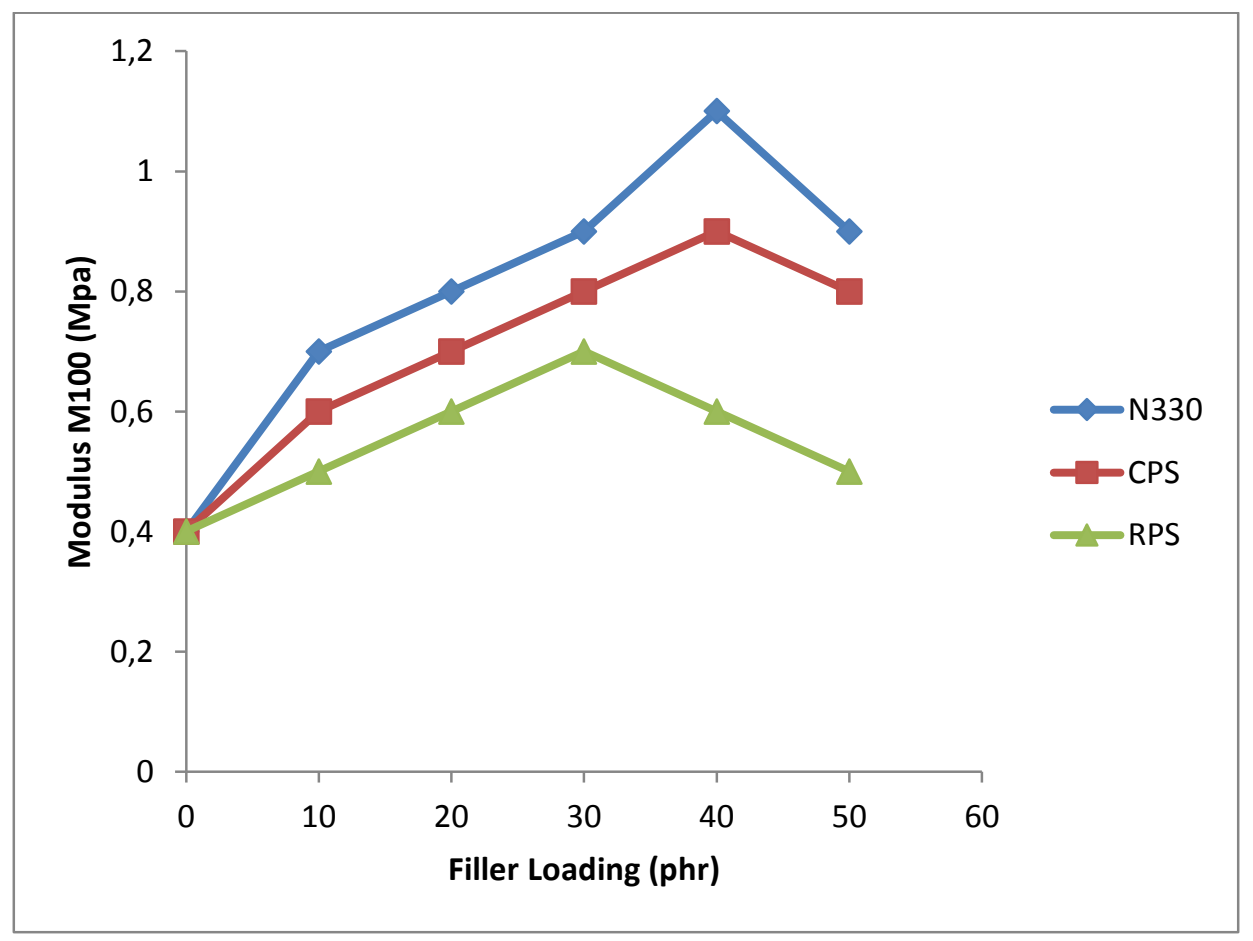

Figure 5: Effect of filler loading on modulus of SNR 10 filled with N330, CPS and RPS. 


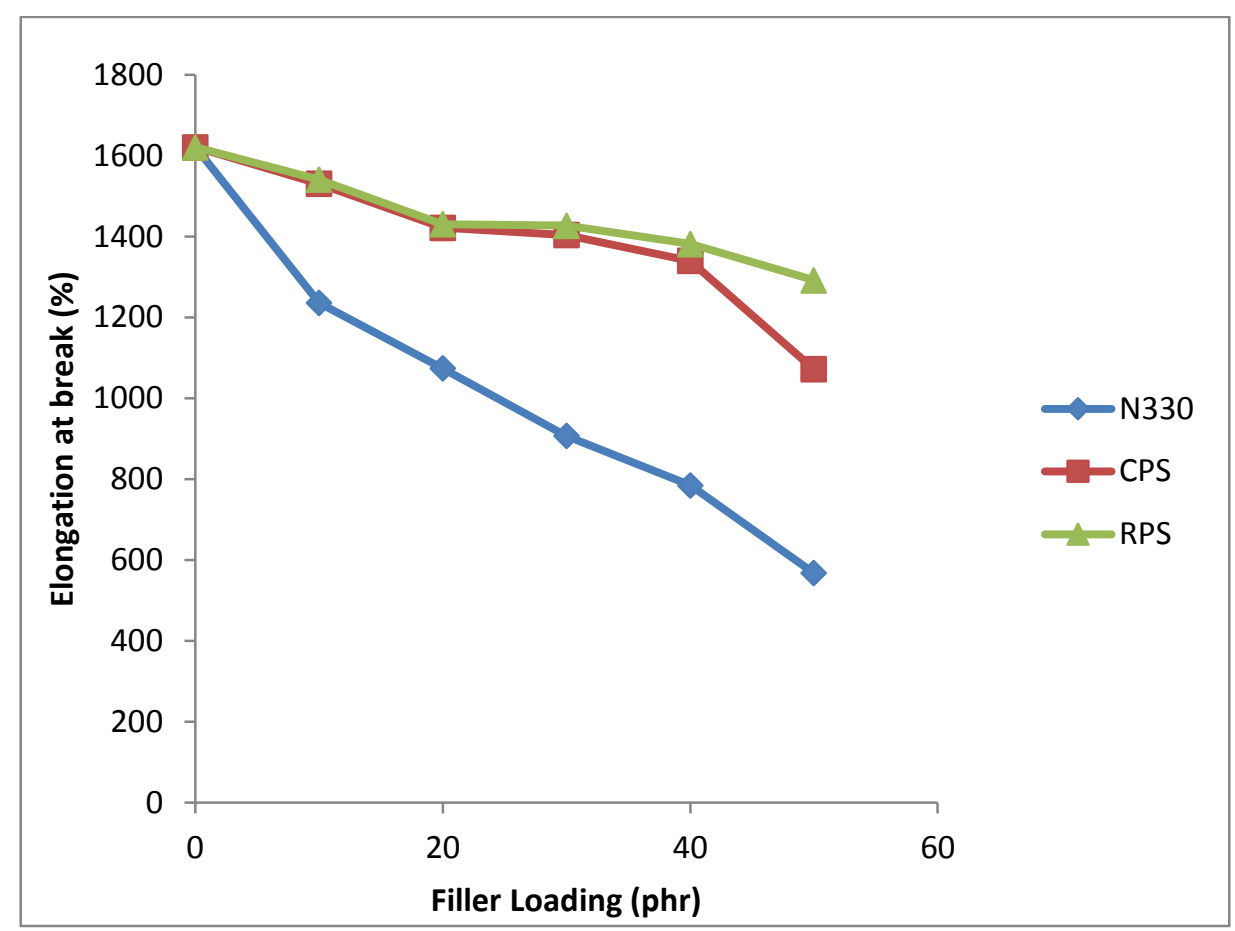

Figure 6: Effect of filler loading on Elongation at break of SNR 10 filled with N330, CPS and RPS.

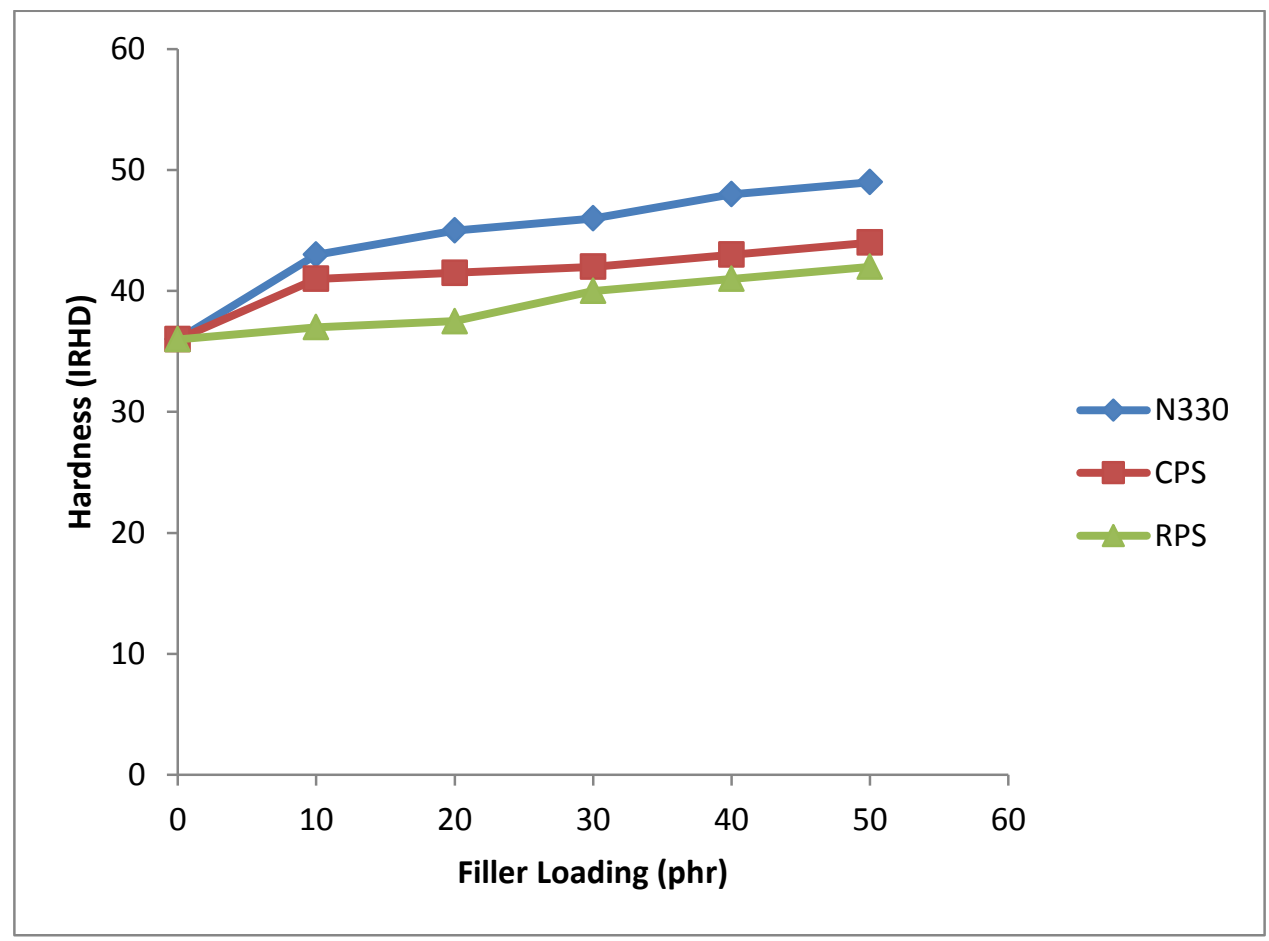

Figure 7: Effect of filler loading on hardness of SNR 10 filled with N330, CPS and RPS. 


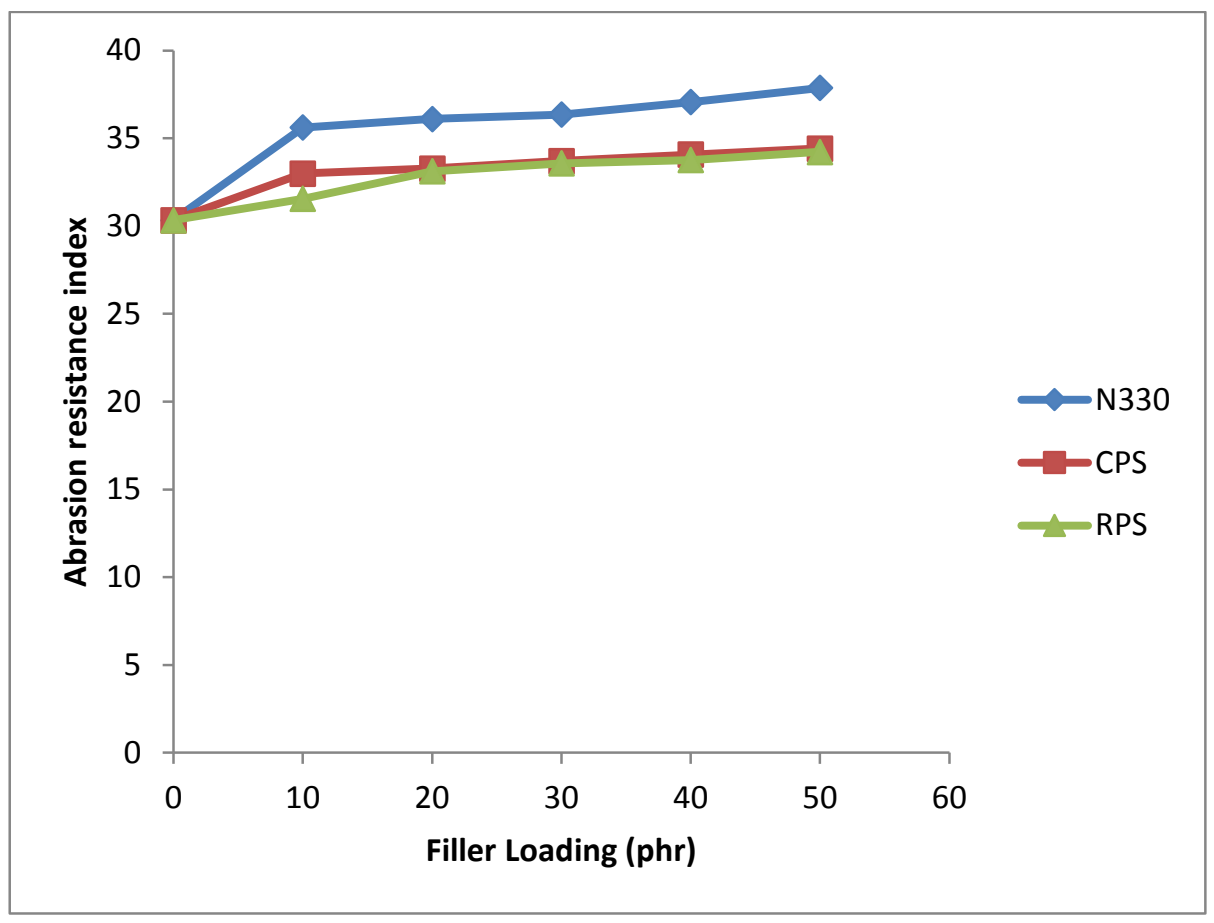

Figure 8: Effect of filler loading on abrasion resistance index of SNR 10 filled with N330, CPS and RPS.

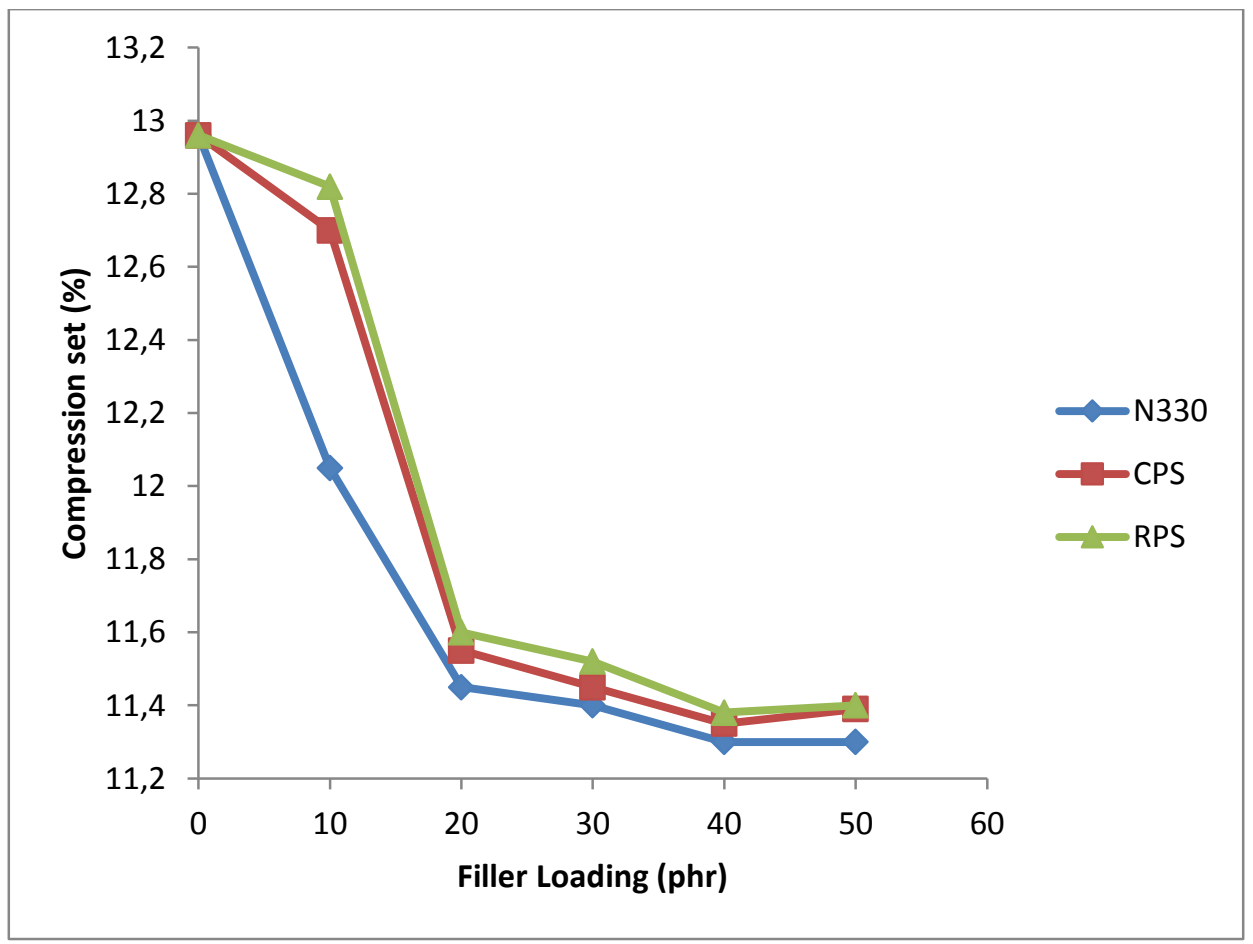

Figure 9: Effect of filler loading on compression set of SNR 10 filled with N330, CPS and RPS. 


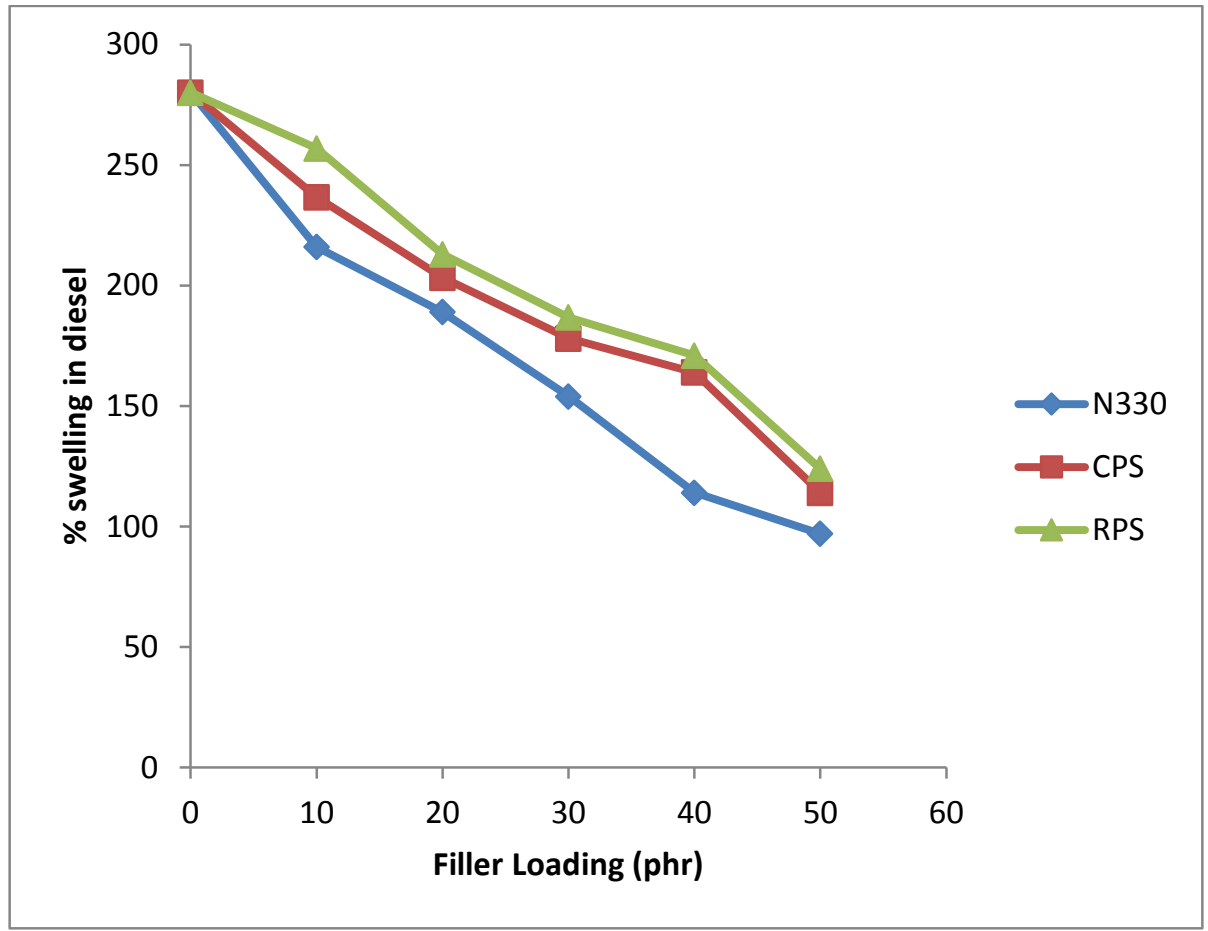

Figure 10: \% Swelling of SNR 10 filled with N330, CPS and RPS in Diesel at $25{ }^{\circ} \mathrm{C}$.

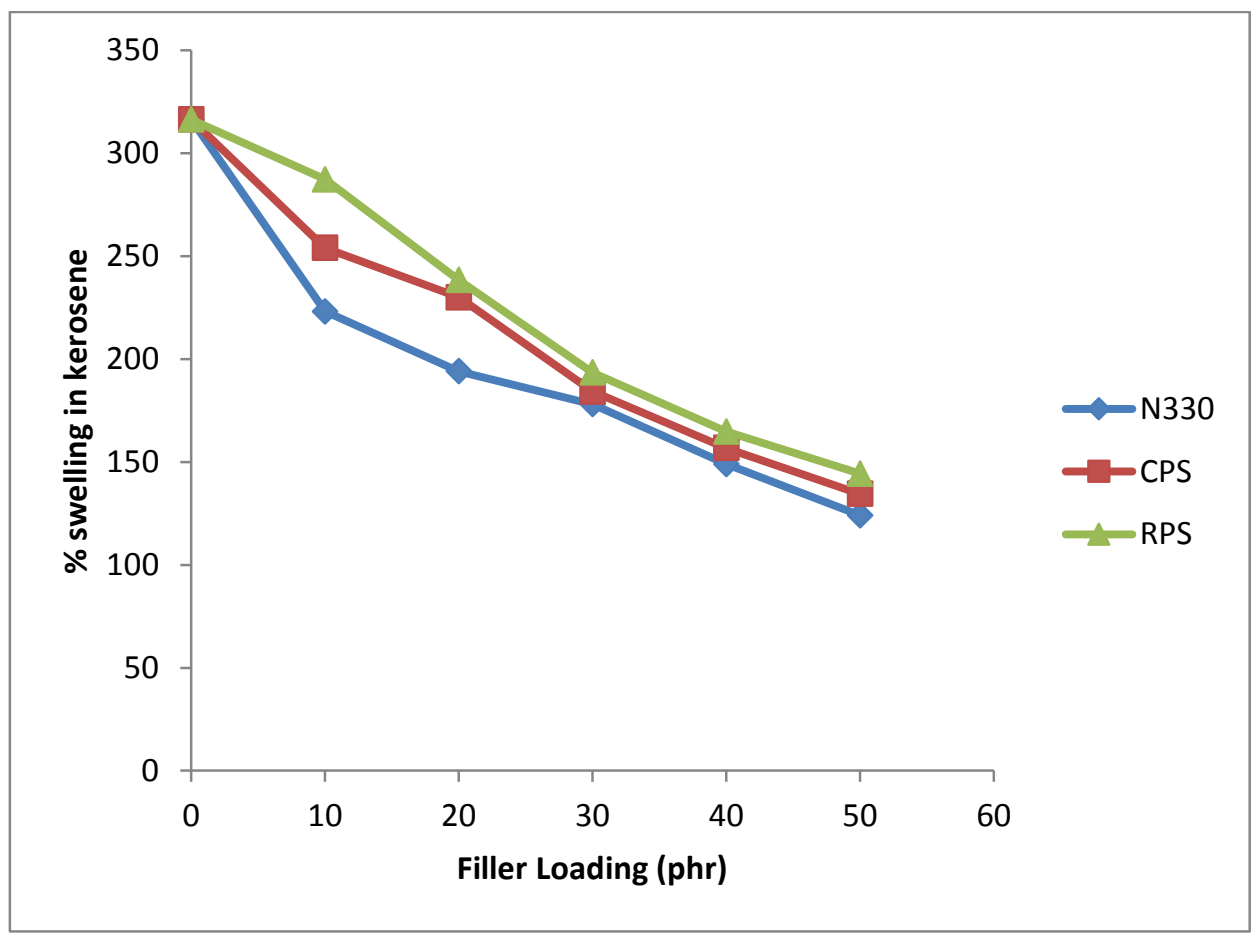

Figure 11: \% Swelling of SNR 10 filled with N330, CPS and RPS in Kerosene at $25^{\circ} \mathrm{C}$. 


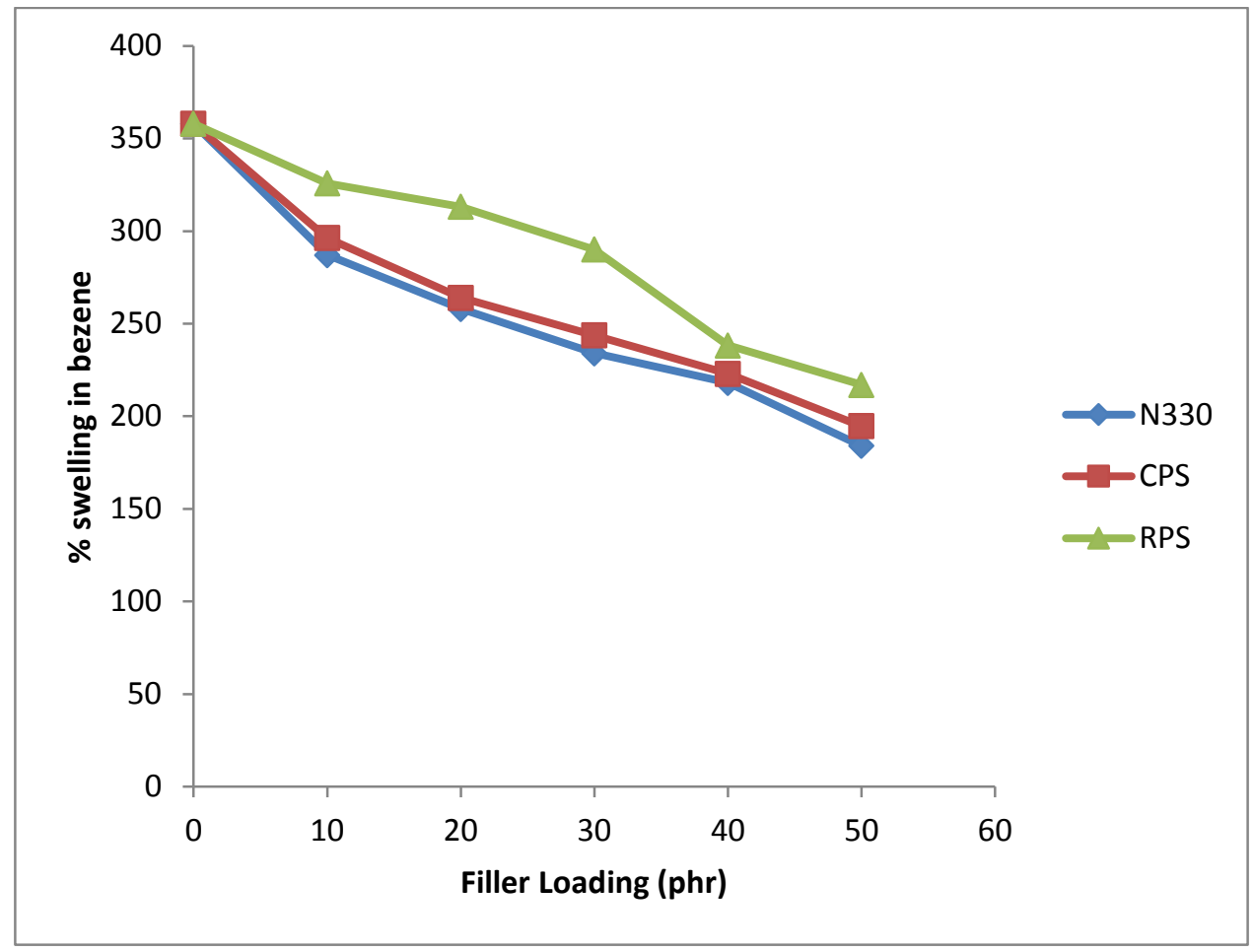

Figure 12: \% Swelling of SNR 10 filled with N330, CPS and RPS in Benzene at $25^{\circ} \mathrm{C}$.

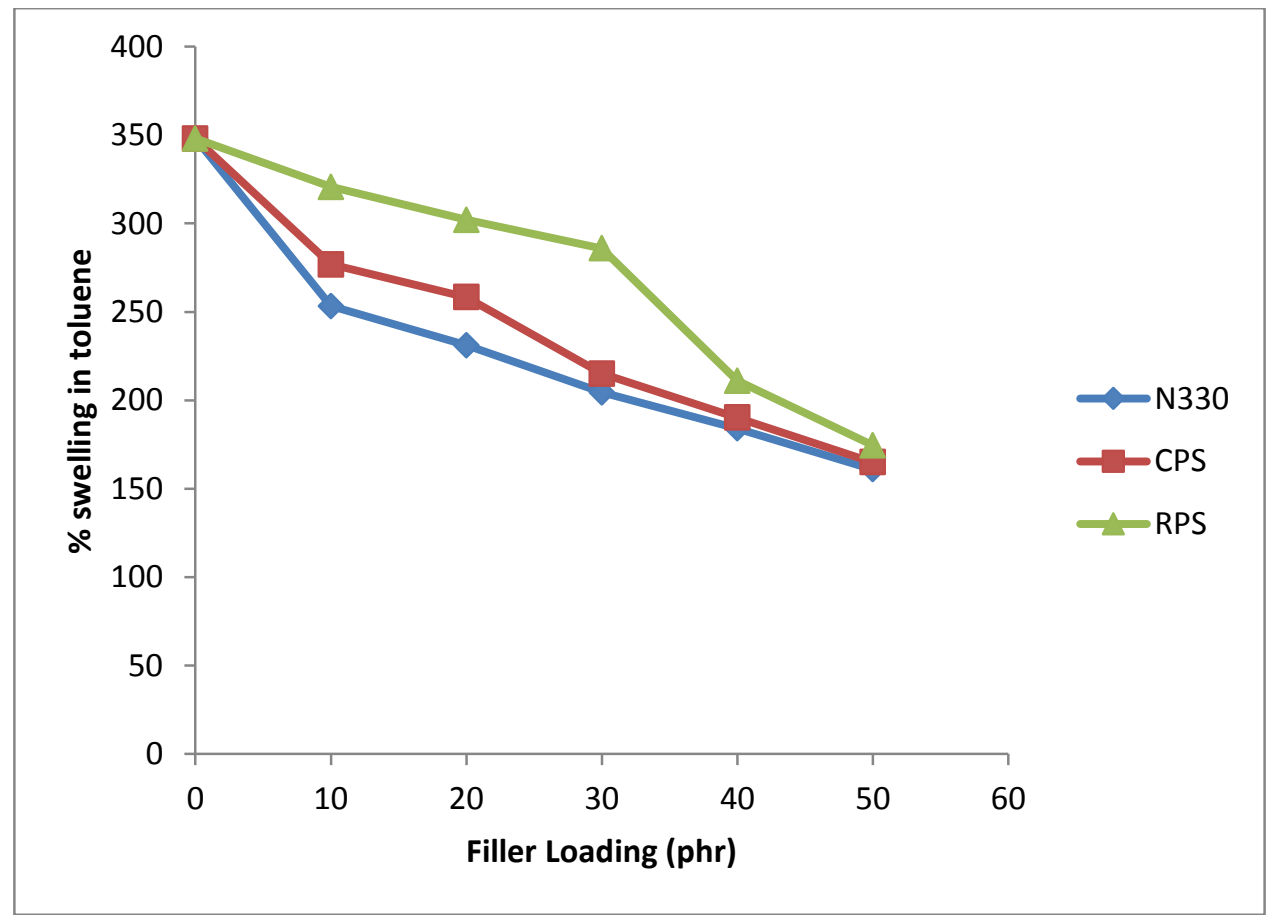

Figure 13: \% Swelling of SNR 10 filled with N330, CPS and RPS in Toluene at $25^{\circ} \mathrm{C}$. 


\section{DISCUSSION}

\section{The Physicochemical properties of N330, CPS and RPS fillers}

Table 2 defines the physicochemical properties of standard Carbon black (N330), CPS and RPS. The moisture contents of CPS and RPS were higher than those of CB (N330). High moisture may impart weak mechanical strength properties to rubber vulcanizates due to lowered filler-rubber matrix interactions (Puglia et al., 2005; Osabohien et al., 2006; Okoh et al., 2014; Osabohien et al., 2015; Osabohien and Ojeifo, 2017). The \% loss on ignition at $1000{ }^{0} \mathrm{C}$ is a measure of carbonaceous content of a material and it is highest in N330 than CPS and RPS (Table 2) And because carbon is a reinforcing element, the more the carbon content the more reinforcing the plant based filler material (Osabohien and Egboh, 2007a; Osabohien and Egboh, 2007b; Onyeagoro, 2012; Osabohien et al., 2015).

Iodine absorption number is a measure of the surface area of a particle and was highest in N330 than CPS and RPS fillers (Table 2). The higher it is, the larger the surface area of the particle, and the finer or smaller the particle. Very fine particle fillers do help promote strong surface contact between fillerpolymer matrix (Osabohien et al., 2006; Okoh et al., 2014; Osabohien et al., 2015; Osabohien and Ojeifo, 2017). The RPS aqueous slurry has a higher $\mathrm{pH}$ value than N330 and CPS. Acidic fillers have been shown to retard cure rates while alkaline fillers enhance cure rates (Osabohien and Ojeifo, 2017).

Figures 1-3 show the effects of filler loading on scorch, cure times and maximum torques of the SNR 10 vulcanizates, however, the decrease in scorch and cure times show that the fillers are slightly acidic and hence caused slight cure enhancements (Okoh et al., 2014). N330 filler showed least metallic and nonmetallic contents than those of CPS and RPS. High metallic contents in fillers may cause cure enhancement. According to Osabohien (2012), in his work titled: "Bowstring hemp fiber reinforced epoxidized natural rubber compounds" showed that fillers with high levels of metal contents resulted in faster cure rates. Therefore, the differences in cure characteristics of vulcanizates may arise from the different filler properties such as moisture content, particle size, surface area, surface reactivity, $\mathrm{pH}$ and metallic contents (Osabohien and Egboh, 2007b; Osabohien, 2012).

N330 filled SNR10 vulcanizates had lower scorch and cure times than CPS and RPS - filled SNR 10 vulcanizates. This may be due to its least acidity and hence, caused most cure enhancement compared to CPS and RPS fillers. Similar observations have been made by previous researchers (Mohamad et al., 2008; Osabohien and Egboh, 2008; Okoh et al., 2014). The essence of curing is basically to form chemical cross-links which can convert the long linear polymer chains into a three dimensional network structure under pressure by the action of heat (Osabohien and Ojeifo, 2017). Maximum torques of the vulcanizates increased as filler loading increased. This shows a good filler- rubber matrix interactions and also a good interfacial bonding between the filler and rubber matrix. This is similar with reports made in earlier studies (Okoh et al., 2014, Osabohien and Ojeifo, 2017). The lower torque values of CPS and RPS - filled systems compared to that of N330 is possibly due to a weaker CPS and RPS filler-rubber matrix interactions which might have caused lower crosslink density. This may be as a result of larger particle sizes and higher moisture contents of the CPS and RPS sourced fillers (Table 2).

\section{Physicomechanical properties of SNR 10 vulcanizates}

Figures 4-9 showed the summary of the physicomechanical properties of SNR 10 vulcanizates filled separately with N330, CPS and RPS at different filler loadings. The tensile strength and modulus at $100 \%$ strain increased with increase in filler content to an optimum level of $40 \mathrm{phr}$. The increase in tensile strength may be as a result of the large surface area (small particle size) of the filler which allowed a possible optimum filler-rubber matrix interaction. Similar observations have been reported by (Imanah and Okieimen, 2004; Mohamad et al., 2008; Osabohien, 2012; Osabohien and Ojeifo, 2017). Tensile 
properties are measures of the ability of a polymeric material to withstand possible stress which can pull it apart and also determine the extent the material can stretch without breaking (Wang et al., 2003; Osabohien and Ojeifo, 2017). The decrease in tensile strength beyond $40 \mathrm{phr}$ filler content, may be attributed to the fact that there was not enough polymer matrix to hold the filler particles together and also may be due to filler agglomeration forming a domain that acts like a foreign body leading to a phase inversion due to diminishing volume fraction of polymer (rubber) in the vulcanizates (Osabohien and Egboh, 2007b; Osabohien and Ojeifo, 2017).

CPS though inferior to N330 filler showed a superior reinforcing ability to RPS. This may be associated with the increased carbon content present in the CPS and smaller particle size due to carbonization as compared to the RPS, there existed increased dispersion and interfacial bonding between the filler and rubber matrix. Similar observation was made by Osabohien (2010). The elongation at break of all the filled vulcanizates decreased with increase in filler content. There be restriction to free mobility of the macromolecular chains by the filler particles which increased the resistance to stretch on application of strain, this may be responsible for the decrease as filler loading was increased (Okoh et al., 2014; Osabohien and Ojeifo, 2017).

However, hardness and abrasion resistance increased with increased, while compression set decreased with increasing filler load of the vulcanizates (Fig. 7-9). This is a clear indication of reinforcement by the fillers. Similar observations have been reported by previous researchers (Igwe and Ejim, 2011; Okoh et al., 2014; Osabohien et al., 2015; Osabohien and Ojeifo, 2017).

Figures 10-13 showed the percentage swelling of the SNR 10 vulcanizates filled with N330, CPS and RPS in petroleum and aromatic solvents (diesel, kerosene, benzene and toluene). Percentage swelling for the vulcanizates in both petroleum and aromatic solvents decreased with increased filler content. Osabohien and Ojeifo (2017) postulated that transport of small molecules through a polymer membrane occurs due to random molecular motion of each molecule, hence the driving force behind the transport process which involves diffusion, sorption and permeation is the concentration difference between the two phases (solvent and polymer phases). Percentage swelling in the aromatic solvents for N330 - SNR 10, CPS -SNR 10 and RPS - SNR 10 was higher than in petroleum solvents, this may be probably due to higher molecular weight of the petroleum solvents. The smaller the molecular weight or size of solvent, the higher its diffusion into the rubber matrix, hence the higher the swelling may become and vice versa. Mathew et al., (2006), showed that lower molecular size of solvents enables them to diffuse faster into polymer vulcanizates therefore increasing swelling. Degree of cross-links, molecular weight or size, inter-molecular forces, liquidliquid and liquid-polymer molecular interactions are factors responsible for swelling or limited solubility of polymer materials in solvents (George and Thomas, 2001; Okiemen and Imanah, 2005; Osabohien, 2010). Also, the better the cross-links between filler and polymer matrix, the higher resistance to swelling of the vulcanizates in both petroleum and aromatic solvents (Osabohien and Ojeifo, 2017). The order of swelling in the solvents is RPS - SNR $10>$ CPS - SNR $10>$ N330 - SNR 10 vulcanizates, which shows the order of increasing filler - rubber crosslinks and reinforcement.

\section{Conclusion}

This study has shown that CPS and RPS fillers can be used as reinforcing and semireinforcing fillers respectively. However, their reinforcing potentials which are somewhat inferior to that of carbon black can be improved by improved pulverization and screening. By these, the particle sizes, surface areas and the interfacial bonding between filler-rubber matrix can be improved for better reinforcement.

\section{COMPETING INTERESTS}

The authors declare that they have no competing interests. 


\section{AUTHORS' CONTRIBUTIONS}

EO was involved in the original design, supervision, compilation of results and write-up of this piece of research work. US was involved in the laboratory experimental work and the financing of the research work. NOO was involved in the laboratory experimental work, assisted in financing and in the final write-up of the research work.

\section{ACKNOWLEGEMENTS}

The authors wish to acknowledge with thanks the Department of Polymer Technology, Auchi Polytechnic, Auchi, Edo State and also the management and laboratory personnel of Rubber Research Institute, Iyanomo, Edo State, Nigeria, for giving us the opportunity to use their laboratories and equipment for this work.

\section{REFERENCES}

Abu-Bakar MAI, Ahmed S, Kuntjoro W. 2012. Effect of epoxidized natural rubber on mechanical properties of epoxy reinforced fibre composites. Pertanika Journal of Science Technology, 20(1): 129-137.

Akinlabi AK, Olayinka OM, Dare EO. 2011. The use of Pterocarpus santalinoides in Rubber Compounding. Scientific Research and Essay, 6(3): 516-521.

ASTM D1512-15. 2015. Standard Tests Methods for Carbon black - $\mathrm{pH}$ value. ASTM D1512-15, 4p.

ASTM D412. 2010. Standard Test Method for Tensile Properties of Elastomers. ASTM D412, 14p.

BS903-A26. 1995. Method of determination of hardness. British Standard Institutions (BSI) methods of testing vulcanized rubber.

BS903-A9. 2012. Method for determination of abrasion resistance. British Standard Institutions (BSI) testing methods for vulcanized rubber.

Blow CM, Hepburn C. 1982. Rubber Technology and Manufacture ( $\left.2^{\text {nd }} \mathrm{edn}\right)$. Butterworth Scientific: London.

Chaiwat R, Wasaphon W, Apikiat S, Yupaporn R. 2013. Cogon grass fibre-epoxidized natural rubber composites. Advance
Materials Research, 747: 375-378. DOI: 10.4028/www.scientific.net/AMR.747.3 75

Der Marderosian A, Beutler JA. 2010. The Review of Natural Products: the most complete source of natural product information. In Health: Facts and Comparison, Wolters K (6 ${ }^{\text {th }}$ ed.). Editions St. Louis.

George SC, Thomas S. 2001. Transport phenomena through polymeric systems. Progress in Polymer Science, 26(6): 9851017. DOI: https://doi.org/10.1016/S00796700(00)00036-8

Heywood VH, Brummitt RK, Culham A, Seberg O. 2007. Flowering Plant Families of the World. Firefly books: United Kingdom.

Igwe OI, Ejim AA. 2011. Studies on mechanical and end-use properties of natural rubber filled with snail shell powder. Materials Sciences and Application, 2(7): $109 . \quad$ DOI: 10.4236/msa.2011.27109

Imanah JE, Okieimen FE. 2004. Studies on the mechanical properties of natural rubber reinforced with agricultural by-products. Proceedings of $27^{\text {th }}$ International conference of Chemical Society of Nigeria, Benin.

Imoisili PE, Ukoba KO, Adejugbe IT, Adgidzi D, Olusunle SOO. 2013. Mechanical Properties of Rice Husk /Carbon Black Hybrid Natural Rubber Composite. Chemistry and Materials Research, 3: 8.

Matthew L, Joseph KU, Joseph R. 2006. Swelling behaviour of isora natural rubber composites in oils used in automobiles. Bullentin of Materials Science, 29(1): 91-99. DOI: 10.1007/BF02709362

Mohamad N, Muchtar A, Ghazali MJ, Muhd D, Azhari CH. 2008. The effect of filler on epoxidized natural Rubber-Alumina nanoparticles composites. European Journal of Scientific Research, 24(4): 538-547.

http://www.eurojournals.com/ejsr.htm 
Morton JF, Miami FL. 1987. Papaya. In Fruits of Warm Climates, Morton J (Ed). Florida flair Books: Miami; 336-346.

Okieimen FE, Imanah JE. 2005. Physicomechanical and equilibrium swelling properties of natural rubber filled with rubber seed shell carbon. Journal of Polymer Materials, 22(4): 409- 416.

Okoh BE, Osabohien E, Egboh SHO. 2014. The reinforcing potentials of Velvet tamarind seed shell as filler in natural rubber compounds. International Journal of Biological and Chemical Sciences, 8(5): 2367-2376. DOI: http://dx.doi.org/10.4314/ijbcs.v8i5.39

Okoh BE, Osabohien E, Egboh SHO. 2008. Effects of alkali pretreatment of groundnut shell filler on the Physicomechanical and Equilibrium Swelling properties of natural rubber vulcanizates. Nigerian Journal Science Environment, 6: 195-201

Onyeagoro GN. 2012. Cure characteristics and physico-mechanical properties of carbonized bamboo fibre filled natural rubber vulcanizates. International Journal of Modern Engineering Research, 2(6): 4683-4690.

Osabohien E, Egboh SHO. 2007a. Cure characteristics and physico-mechanical properties of natural rubber filled with seed shells of cherry (Chrysophyllum albidum). Journal of Applied Sciences and Environmental Management, 11(2): 430-348.

DOI: 10.4314/jasem.v11i2.54983

Osabohien E, Egboh SHO. 2007b. An investigation on the reinforcing potential of red earth as filler in natural rubber compounds. Journal of Applied Polymer Science, $\quad \mathbf{1 0 5}(2)$ : 515-520. DOI: https://doi.org/10.1002/app.26244

Osabohien E. 2010. Potential of carbonized cherry seed shell as filler in natural rubber vulcanizates. Journal of Polymer Materials, 27(4): 379-389.

Osabohien E. 2012. Bowstring hemp fiber reinforced epoxidized natural rubber compounds. Journal of polymer Materials, 29(4): 423- 435.
Osabohien E. 2012. The physico-mechanical properties of natural rubber filled with cherry seed shell-carbon-black blends. ASUU Journal of Science, 1(1): 21-39.

Osabohien E, Egboh SHO. 2008. Utilization of bowstring hemp fiber as filler in natural rubber compounds. Journal Applied Polymer Science, 107(1): 210-214. DOI: 10.1002/app.27012

Osabohien E, Ojeifo NO. 2017. The reinforcing potentials of white sand as filler in natural rubber vulcanizates. Nigerian Journal of Polymer Science and Technology, 12: 57- 66.

Osabohien E, Egboh SHO, Okoh BE. 2006. The cure characteristics and physicomechanical properties of natural rubber filled with pineapple leaf fibre. Journal of Bioscience and Biotechnology Resources Asia, 4(1): 111-116.

Osabohien E, Okoh BE, Egboh SHO. 2015. Calamus deerratus fibre reinforced natural rubber vulcanizates. International Journal of Biological and Chemical Sciences, 9(2): 1094-1106. DOI: 10.4314/ijbcs.v9i2.45

Puglia D, Biagiotti J, Kenny JM. 2005. Applications of natural reinforcements in composite materials for automotive industry. Journal of Natural Fibre, 1(3): 23-65.

DOI: https://doi.org/10.1300/J395v01n03_03

Sogbaike OE, Okieimen FE, Edojariogba PO. 2005. Effects of substitution of carbon black (N330) with carbonized plantain peels on cure characteristics, physicomechanical and swelling properties of natural rubber vulcanizates. Chem. Tech. Journal, 1: 24-29.

Vogel AI. 1978. A Textbook of Quantitative Inorganic Analysis Including Elementary Instrumental Analysis ( $4^{\text {th }}$ ed.). Longman: London.

Wang R, Panighrahi S, Tabil L, Grerar W, Powell T, Kolybaba M, Shokhansani S. 2003. Flax fibre-reinforced thermoplastic composites, CSE/ASAE. Annual International meeting, Fargo, 1-14. 